\title{
Lost in the South: A Roman Copper Ingot From the AREA of TARRAgONA IN THE BAETICA
}

\author{
Michael Bode \\ Deutsches Bergbau-Museum Bochum, Germany \\ Peter Rothenhoefer \\ Kommission für Alte Geschichte und Epigraphik, München, Germany \\ Diego González Batanero \\ Ánfora Gestión Integral del Patrimonio S.L. Huelva. Spain
}

Recibido: 18/04/2018

Aceptado: 31/05/2018

Revisado: 14/05/2018

Publicado: 29/06/2018

\section{RESUMEN}

Se presenta un lingote de cobre romano recuperado de un pecio ubicado en la región fronteriza de las provincias de Málaga y Cádiz. Con un diámetro de $45 \mathrm{a} 53 \mathrm{~cm}$ y un peso de $75.4 \mathrm{~kg}$, es uno de los galápagos de cobre más pesados que se conocen. La abreviatura de un nombre y su peso están escritos cerca del borde del fondo. El análisis de los isótopos de plomo y los elementos traza sugieren una procedencia no de minas del sur de Hispania, sino de la región de Cataluña en el noroeste de la península ibérica.

\section{Palabras Clave}

lingote de cobre romano; Inscripción; Pecio Baetica; estudio de procedencia; Análisis de los isótopos de plomo; Minas de Cataluña

\section{ABSTRACT}

A Roman copper ingot recovered from a wreck located in the border region of the provinces of Málaga and Cádiz is presented in the following contribution. With a diameter of 45 to $53 \mathrm{~cm}$ and a weight of $75.4 \mathrm{~kg}$ it is one of the heavier specimens. Presumably the abbreviation of a name and the indication of its weight were incised near the rim of the bottom. Lead isotope and trace element analysis suggest a provenance not from mines in southern Hispania, but from the polymetallic ores of the Catalunya region in northeastern Spain.

\section{KEY WORDS}

Roman copper ingot; Inscription; Provenance studies; Lead isotope analysis; Baetica; Mines of Catalunya

michael.bode@bergbaumuseum.de

peter.rothenhoefer@dainst.de

diego@anforagrupo.com 
A Roman copper ingot (figure 1), discovered at the mediterranean south coast of Spain between Cadiz and Málaga and then stored for several years at a private collection, was given recently to the Museo de Huelva. The find spot of the ingot is only vaguely known: it was recovered from a undocumented shipwreck located in the border region of the provinces of Málaga and Cádiz (figure 2; between Gibraltar in the south and Estepona in the north?) at a shallow depth. Traces of seaencrustations on the greenish surface confirm an origin from an underwater site.

The ingot is of the typical "bun-shaped" form, „that is, round, flat-bottomed, with a convex upper

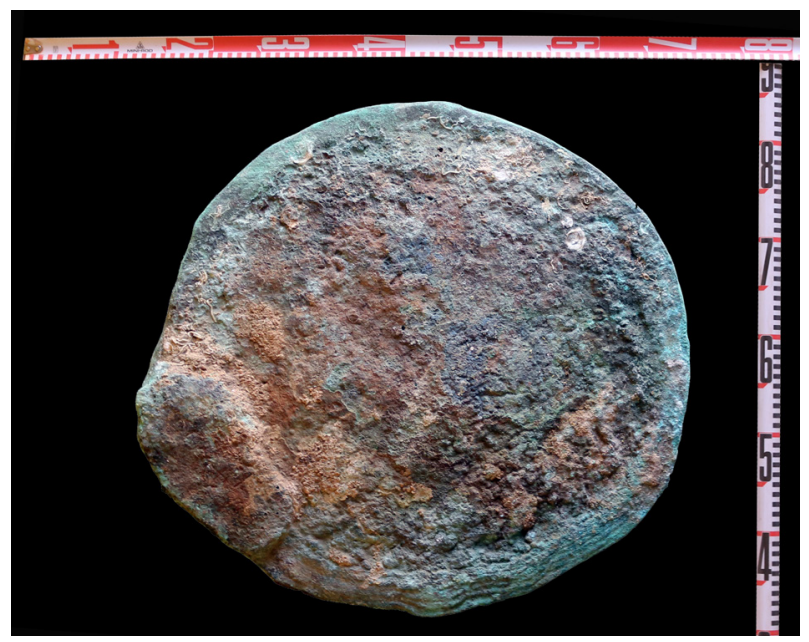

Figure 1. Copper ingot in the Museo de Huelva (D. González Batanero).

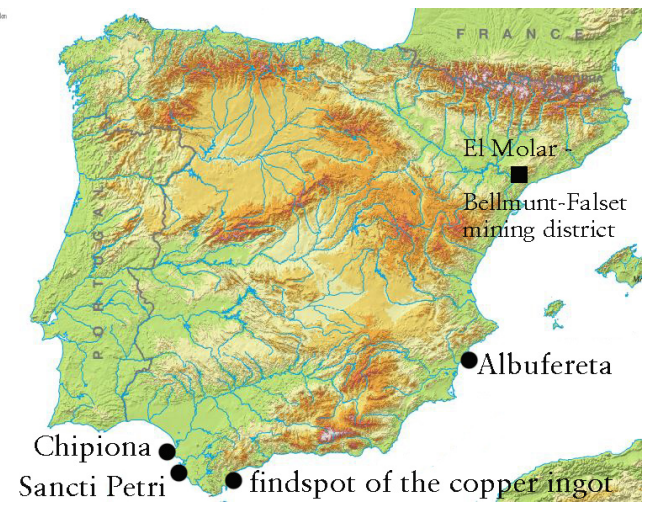

Figure 2. Map of the Iberian Peninsula with the main find spots of copper ingots mentioned in the text (P. Rothenhöfer). surface“. ${ }^{1}$ With a diameter between 45 and $53 \mathrm{~cm}$, a height of 8 to $10 \mathrm{~cm}$, and a weight of $75.4 \mathrm{~kg}$, it is one of the larger and heavier specimens. For comparison: The 16 copper ingots periodically discovered in 1992 during dredging works in the sea near the mouth of the Guadalquivir river, not far from Playa de Regla at Chipiona (Cádiz), weigh between 13.7 and $20.6 \mathrm{~kg}$; their dimensions vary between 23-29.5 cm and the heights from 3.5 to 6 $\mathrm{cm}^{2}$ Wider variations in weight can be observed within the group of the 28 copper ingots from the 1st century AD wreck "El Pecio del Cobre", which were recovered in 1978-1979 from the seabed west of Islote de Sancti Petri, Chiclana de la Frontera (Cádiz): ${ }^{3}$ from 13, 14, and $16 \mathrm{~kg}$ to 68 and even 84 $\mathrm{kg}$ (the latter one with a diameter of $44.5 \mathrm{~cm}$ and a height of $12 \mathrm{~cm}$ ). The diameters of the 11 copper ingots from the Roman wreck at Albufereta (Alicante) are $45-50 \mathrm{~cm}$ at the bottom and 25-30 $\mathrm{cm}$ on the top; their height varies between 12-17 $\mathrm{cm}^{4}$

Heavier ingots are known, for instance, from the looted mid-2nd century wreck Planier 2, located off Marseille: the weight of one of them is $97 \mathrm{~kg}$.

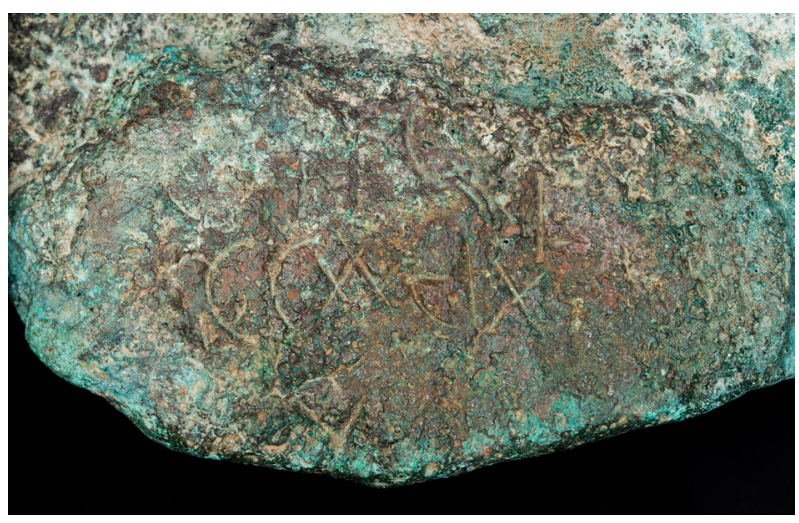

Figure 3. Detail of the copper ingot with incised inscriptions (D. González Batanero).

1 See the introductory remarks to RIB II/1, 2403 (Copper Ingots) and Laubenheimer-Leenhardt 1973, 67-70; cf. e.g. Vallespín Gómez 1986, 310-311.

2 Rico et Domergue 2010, 175 with data of 16 ingots.

3 See Vallespín Gómez 1986, 311 Table 1. - A second wreck with at least 70 copper ingots was recently discovered.

4 Fernández Izquierdo, 2007, 237-238 (without indication of the weight).

5 Laubenheimer-Leenhardt 1973,36-37 no.16 (wrongly attributed to the wreck Planier 4). 


\begin{tabular}{|c|c|c|c|c|c|c|c|c|c|c|c|c|c|c|c|}
\hline lab-no. DBM & arch.-inv. & $\mathrm{Ag}$ & $\mathrm{Sn}$ & $\mathrm{Sb}$ & $\mathrm{Pb}$ & $\mathrm{Bi}$ & $\mathbf{P}$ & $\mathrm{s}$ & $\mathrm{Fe}$ & Co & $\mathrm{Ni}$ & $\mathrm{Zn}$ & As & $\mathrm{Se}$ & $\mathrm{Cu}[\%]$ \\
\hline $4513 / 16$ & Cobre TT & 300 & 10 & 1000 & 450 & 15 & 10 & 420 & 50 & 2,5 & 190 & 15 & 470 & 65 & 99 \\
\hline
\end{tabular}

Figure 4.Trace elements (ppm) and chemical composition (M. Bode).

\begin{tabular}{|l|c|c|c|c|c|c|c|c|c|c|c|c|}
\hline lab-no. DBM & arch.-inv. & ${ }^{206} \mathrm{~Pb} / /^{204} \mathrm{~Pb}$ & $2 S D(a b s)$ & ${ }^{207} \mathrm{~Pb} /{ }^{204} \mathrm{~Pb}$ & $2 S D(a b s)$ & ${ }^{208} \mathrm{~Pb} /{ }^{204} \mathrm{~Pb}$ & $2 S D(a b s)$ & ${ }^{207} \mathrm{~Pb} /{ }^{206} \mathrm{~Pb}$ & $2 S D(a b s)$ & ${ }^{208} \mathrm{~Pb} /{ }^{206} \mathrm{~Pb}$ & $2 S D(a b s)$ & $\mathrm{Pb}[\mathrm{ppm}]$ \\
\hline $4513 / 16$ & Cobre TT & 18,447 & 0,009 & 15,723 & 0,006 & 38,670 & 0,018 & 0,8524 & 0,0001 & 2,0963 & 0,0002 & 450 \\
\hline
\end{tabular}

Figure 5. Lead isotope ratios (M. Bode).

The ingot consists of highly pure copper with a concentration of $99 \%$. Trace elements are inter alia antimony, arsenic, lead, sulphur, silver, and nickel (figure 4).

The monetary value of the highly pure copper ingot can be estimated roughly: If we assume $10 \mathrm{gr}$ for an $\mathrm{AE}-a s$-coin, than $75 \mathrm{~kg}$ copper are equivalent to 7.500 asses. And 7.500 asses can be changed into 18 aurei and more than a dozen denarii. For comparison: the annual salary of a legionary soldier in the early principate was 225 denarii $=9$ aurei.

Many of the Roman copper ingots bear marks and inscriptions. But in contrast to Roman lead ingots, the epigraphy of copper ingots is poorer: ${ }^{6}$ There are no moulded cartouches with names of societates, entrepreneurs, or even of an emperor; usually we only find stamps and/or incised letters - mostly numerals. ${ }^{7}$

Not just numbers, but also letters are found on this ingot (figure 3). They are incised on a lump near the rim. Their height is ca. $2-2.5 \mathrm{~cm}$. Three lines can be distinguished:

\section{$Q H G \quad I$ ? \\ CCXX ET X \\ $C$ ? $V$}

In the first line we can read the letters $Q H G$ and at the end - slipped down - an $I$ (or perhaps an E?). Presumably it is the abbreviation of a name (in the genitive): $Q$ (uinti) $H(\ldots) G(\ldots)$ [maybe $G i(\ldots)$ or $G e(\ldots)]$.

The second line consists of a number: $C C X X$ $E T X=220$ and 10 librae. The sum of 230 Roman librae is equivalent to ca. $75 \mathrm{~kg}$, undoubtedly the indication of the weight. The use of et (with

6 For the epigraphy of Roman lead ingots, see Rothenhoefer, Bode and Hanel, Corpus of Roman Lead Ingots (forthcoming).

7 See e.g. Rico et Domergue 2010, 174-178; longer texts are only known from two ingots (Laubenheimer-Leenhardt 1973, 36-37 no. 16 and 52-55 no. 24). lunar E) within a number is, as far as we can see, uncommon for ingots. We would normally expect $C C X X X$.

et is used, for instance, in the funerary inscription AE 1942/43, 78 from Tiaret (Mauretania Caesariensis): an(no) pro(vinciae) CCCLXX et $V(=\mathrm{AD} 324)$; in a Christian funerary inscription from Mérida, AE 2001, 1167: ... XXX et VIIII annorum; or in the funerary inscription ICUR 1, 2251 from Rome: ... annos XX et VI ... . Its use in figures of ancient inscriptions seems to be a phenomenon predominantly of late antiquity. As long as we have no other dating criteria, it can be a vague hint for the age of the ingot.

The indication of the weight corresponds well with its actual weight. The same can be observed on other ingots, for instance on an ingot from the Planier 2-wreck: it weighs $97 \mathrm{~kg}$, and it bears the incised number CCXCVII (= 297 librae). Obviously, the weight of copper ingots was exactly noticed.

In the third line only two letters can be read: $C($ ?) $V$. If there were more letters incised, they have vanished completely.

Regarding the findspot of the ingot, it consequently should have been produced in mines of southern Spain, either in the Iberian Pyrite Belt or the Ossa Morena zone. A lead isotope analysis in addition to the chemical analysis should clarify this point (fig. 4-6).

ROMAN COPPER INGOTS AND THEIR PROVENANCE BY LEAD ISOTOPE ANALYSIS

For all published Roman copper ingots, for which a lead isotope investigation has been made, an origin can be derived from copper mines of the western Mediterranean. ${ }^{8}$ The numerous copper ingots from the shipwrecks Sud Lavezzi 2, Lavezzi 1 and Pecio del Cobre (fig. 6, blue crosses) are most likely from the massive sulfide deposits of the Iberian Pyrite Belt in southern Portugal (e.g.

8 Klein et al. 2007; Klein et al. 2009; Rico et al. 2005. 


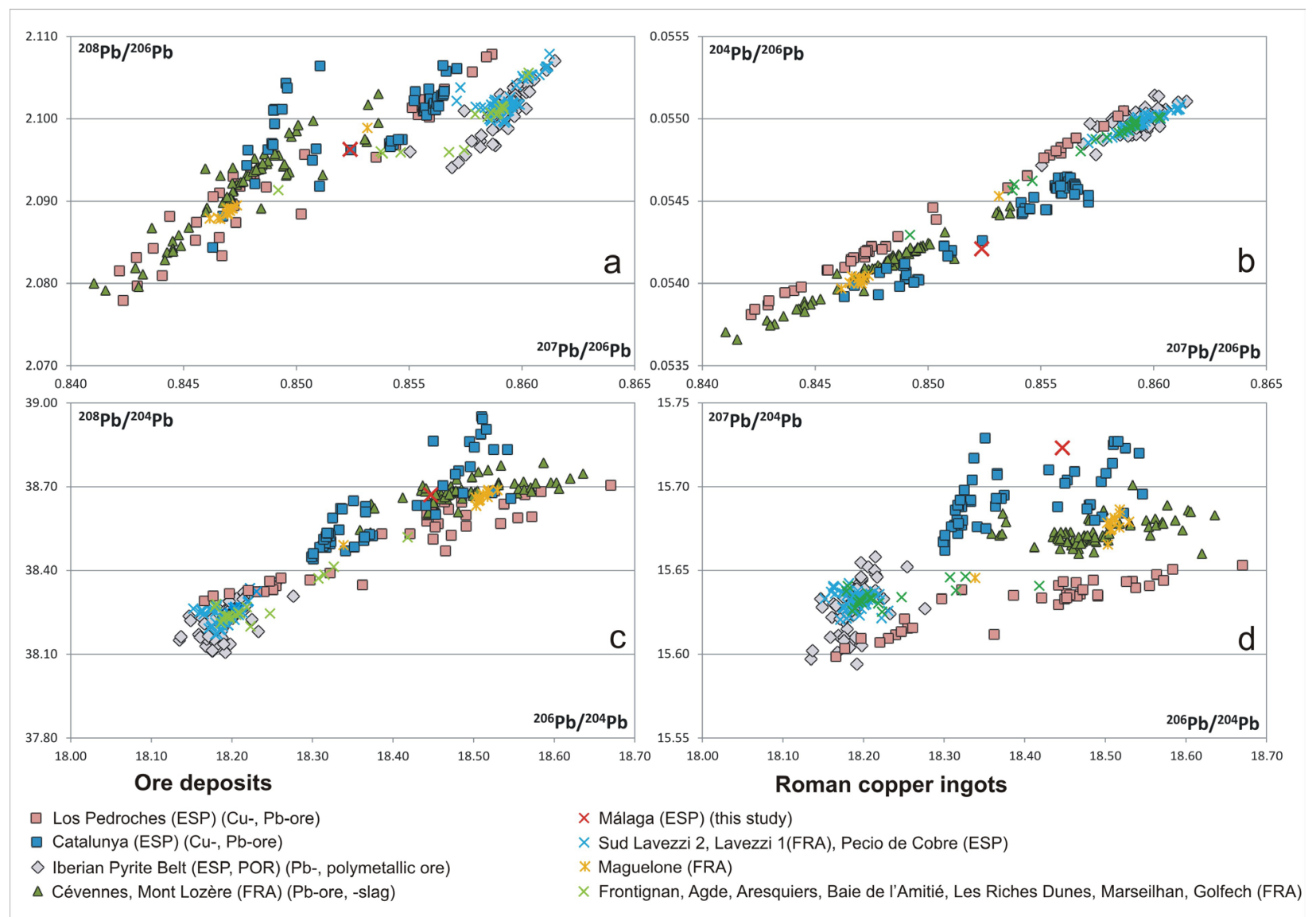

Figure 6. Diagrams with different lead isotope ratios. Ore and copper ingot data: Brévart et al., 1982; Stos-Gale et al., 1995; Canals i Cardellach, 1997; Lescuyer et al., 1998; Marcoux, 1998; Pomiès et al., 1998; Santos-Zalduegui et al., 2004; Rico et al., 2005; Baron et al., 2006; Klein et al., 2007, 2009; Rovira et al., 2013 (M. Bode).

Aljustrel/ancient Vipasca) and southern Spain (Riotinto).

Similarly, a whole series of Roman copper ingots found off the French coast or on the French mainland have been shipped from the southern Iberian peninsula (figure 6 , green crosses), made also from ore of the Iberian Pyrite Belt or from the central-Iberian Zone (Los Pedroches). ${ }^{9}$

In contrast to previous hypothesis concerning the origin of the copper bars of Maguelone, the lead isotope comparison leads to a different result. With a look at diagrams $\mathrm{b}$ and $\mathrm{d}$ of figure 6 , an origin from the Cévennes ore district in southern France is far more likely, contrary to the assumption of Christian Rico et al. that the ingots were produced in mines of Los Pedroches. ${ }^{10}$ In addition to numerous archaeological evidence for Roman

9 Klein et al. 2007 and 2009.

10 Rico et al. 2005, 466-469. mining ${ }^{11}$, it has recently been shown that for the Cévennes not only a local limited metal production is to be assumed, but also supraregional supply of metals (lead, silver, and brass). ${ }^{12}$

And if calamine for brass production, e.g. in Lyon, has been exploited in southern Gaul ${ }^{13}$, then the production of copper is obvious, especially since there is also copper ore. ${ }^{14}$

Sample material of the copper ingot was analyzed at the Deutsches Bergbau-Museum Bochum for the chemical composition (figure 4) and at the Institut für Geowissenschaften in Frankfurt for lead isotope analysis (figures 5). The lead isotope result is surprising: Another old mining area comes into play for the copper

11 See e.g. Davies 1935, 80-83.

12 Hanel and Bode 2016; Parjanadze and Bode (in print). 13 Picon et al. 1995.

14 Cf. e.g. Leblanc 1997. 
ingot from Málaga. Again, the diagrams b and $d$ of figure 6 allow a clear differentiation from the aforementioned mining districts and an association with the polymetallic ores of the Catalunya region in northwestern Spain. Not only lead-silver, but also copper ore smelting is attested from the preRoman periods. ${ }^{15}$ Additionally, the fragment of a copper-lead ingot from the Phoenician period is another hint for pre-Roman copper production in this region. ${ }^{16}$

Up to now discussions about the possible scale of Roman mining activities in that region were focussed on lead-silver production; ${ }^{17}$ a significant Roman copper production in this region was not taken into consideration. This should now be changed.

Unfortunately we lack significant information about the wreck. No information is available neither about the number of copper ingots nor about the rest of the cargo, which could help to date the load. Nevertheless, the ingot allows another important conclusion: Our picture of the prevailing trade direction needs to be reconsidered. Important production centers are known from the southern parts of the Iberian Peninsula. Ingots were brought from the mining areas to the sea inter alia by using rivers like the Guadalquivir/Baetis. After being transhipped to seaworthy vessels, they were transported eastwards to various destinations in the western Mediterranean. But this ingot shows us, that copper was also shipped into the opposite direction: from the area of Tarragona to the Baetica. That reminds us that trade relations and the ways of metal distribution are much more complex than easy models suggest.

15 See e.g. Montero-Ruiz et al. 2009; Rovira et al. 2013. 16 Montero-Ruiz et al. 2009.

17 See e.g. Rafel and Armada 2010 for the mines of the Baix Priorat region.
BIBLIOGRAPHY

RIB = The Roman Inscriptions of Britain.

Baron, S., Carignan, J., Laurent, S., Ploquin, A. (2006), "Medieval lead making on Mont-Lozère Massif (Cévennes-France): Tracing ore sources using $\mathrm{Pb}$ isotopes", Applied Geochemistry 21, 241-252.

Brévart, O., Dupré, B. and Allègre, C. J. (1982), "Metallogenic provinces and the remobilization process studied by lead isotopes: lead-zinc ore deposits from the southern Massif Central, France", Economic Geology 77, 564-575.

Canals, A. and Cardellach, E. (1997), "Ore lead and Sulphur isotope pattern from the lowtemperature veins of the Catalanian Coastal Ranges (NE Spain)", Mineralium Deposita, $32,243-249$.

Davies, O. (1935), Roman mines in Europe, Oxford.

Fernández Izquierdo, A., Berni Millet, P. y Aguilera Martin, A. (2007), "El pecio romano de la Albufereta (Alicante): un documento de época pre-flavia”, Actas $V$ Jornadas Internacionales de Arqueología Subacuática (J. Pérez Ballester y G. Pascual, eds), Valencia, 231-246.

Hanel, N. und Bode, M. (2016), "Messingbarren aus einem römischen Schiffswrack bei Aléria (Korsika)", From Bright Ores to Shiny Metals, Festschrift Andreas Hauptmann, Der Anschnitt Beiheft 29 (G. Körlin, M. Prange, Th. Stöllner und Ü. Yalcin, eds), Bochum, 167181.

Klein, S., Domergue, C., Lahaye, Y., Brey, G. P. and von Kaenel, H. M. (2009), "The lead and copper isotopic composition of copper ores from the Sierra Morena (Spain)”, Journal of Iberian Geology, 35, 59-68.

Klein, S., Domergue, C., Rico, Chr. et Garnier, J.F. (2009), "Sur la signature isotopique du plomb des lingots de cuivre romains découverts il y a trente ans dans le lit de la Garonne, à Golfech (Tarn-et-Garonne)", Aquitana 25, 33-39.

Klein, S., Rico, Chr., Lahaye, Y., von Kaenel, H.-M., Domergue, C. and Brey, G. P. (2007), "Copper ingots from the western Mediterranean Sea: chemical characterization and provenance studies through lead- and copper isotope analyses", Journal of Roman Archaeology, 20, 202-221. 
Leblanc, M. (1997), “Gites et gisements de cuivre de la France meridionale: typologie et caracteristiques geochimiques", Archéologie en Languedoc, 21, 21-26.

Lescuyer, J. L., Leistel, J. M., Marcoux, E., Milési, J. P. and Thiéblemont, D. (1998), "Late Devonian-Early Carboniferous peak sulphide mineralization in the Western Hercynides", Mineralium Deposita, 33, 208-220.

Liou, B. et Domergue, C. (1990), "Le commerce de la Bétique au Ier siècle de notre ère. L'épave Sud-Lavezzi 2 (Bonifacio, Corse du Sud)", Archaeonautica, 10, 11-123.

Marcoux, E. (1998), "Lead isotope systematics of the giant massive sulphide deposits in the Iberian Pyrite Belt", Mineralium Deposita, $33,45-88$.

Montero-Ruiz, I., Gener, M., Renzi, M., Hunt, M., Rovira, S. and Santos-Zalduegui, J. F. (2009), "Provenance of lead in first Iron Age sites in southern Catalonia (Spain)", Proceedings ISA 2006. 36th International Symposium on Archaeometry (J.F. Moreau, R. Auger, J. Chabot, and A. Herzog, eds.), Cahiers d'archéologie du CELAT, 25. Série archéométrie, 7, 391-398.

Parjanadze, T. and Bode, M. (in print), "Roman Silver Objects from the Ancient Kingdom of Kartli (Caucasian Iberia) in Georgia (Mtskheta, Dedoplis Gora [Kareli district]) - a Lead Isotope Investigation”, Metalla

Picon, M., Le Nezet-Celestin, M. et Desba, A. (1995), "Un type particulier de grands recipients en terre réfractaire utilizes pour la fabrication $\mathrm{du}$ laiton par cementation", Productions et importations dans le Nord-Ouest de la Gaule et relations avec la Bretagne romaine. Actualité des recherches céramiques (L. Rivet, ed), Societé Française d'Etude de la Céramique Antique en Gaule, Actes Congrès Rouen, Marseille, 207-215.

Pomiès, C., Cocherie, A., Guerrot, C., Marcoux, E. et Lancelot, J. (1998), "Assessment of the precision and accuracy of lead-isotope ratios measured by TIMS for geochemical applications: example of massive sulphide deposits (Rio Tinto, Spain)", Chemical Geology 144, 137-149.

Rafel, N. i Armada, X.L. (2010), “L'explotació minera al Baix Priorat (Tarragona) en època romana: notes a propòsit del plumbum nigrum oleastrense", Cuadernos de Prehistoria y
Arqueología Castellonense, 28, 247-261.

Rico, Chr., Domergue, C., Rauzier, M., Klein, S., Lahaye, Y., Brey, G., et von Kaenel, H.M. (2005), "La provenance des lingots de cuivre romains de Maguelone (Hérault, France). Étude archéologique et archéométrique”, Revue Archeologique de Narbonnaise, 38, 459-472.

Rothenhoefer, P., Bode, M. and Hanel, N., Corpus of Roman Lead Ingots (forthcoming).

Rovira, C., Montero-Ruiz, I., Rafel, N., Hunt, M., Soriano, I., Murillo-Barroso, M. and Renzi, M. (2013), "Copper ores in the Montsant area (Tarragona, Spain) and their use during the Bronze Age", Poster, 19th Annual Meeting of European Association of Archaeologists, 4-8 September 2013, Pilsen.

Santos Zalduegui, J. F., García de Madinabeitia, S., Gil Ibarguchi, J. I. and Palero, F. (2004), "A lead isotope database: the Los Pedroches - Alcudia area (Spain); Implications for archaeometallurgical connections across southwestern and southeastern Iberia", Archaeometry, 46, 625-634.

Stos-Gale, Z., Gale, N. H., Houghton, J. and Speakman, R. (1995), "Lead isotope data from the Isotrace Laboratory, Oxford: Archaeometry data base 1, ores from the western Mediterranean”, Archaeometry, 37, 407-415.

Vallespín Gómez, O. (1986), “The Copper Wreck (Pecio del Cobre)", International Journal of Nautical Archaeology, 15, 305-322. 